\title{
Wykład otwarty prof. dr. Davida Whitebreada (University of Cambridge) pt. „Zabawa i uczenie się dzieci a wiek rozpoczynania edukacji szkolnej - fakty i mity" (Warszawa, 8 czerwca 2015 r.)
}

Na Wydziale Nauk Pedagogicznych Uniwersytetu Kardynała Stefana Wyszyńskiego w Warszawie w dniu 8 czerwca 2015 roku miał miejsce wykład otwarty Davida Whitebreada $z$ Uniwersytetu Cambridge w Wielkiej Brytanii. Profesor przybył do Polski na zaproszenie Fundacji Rzecznik Praw Rodziców. Naukowo zajmuje się psychologią poznawczo-rozwojową ze szczególnym uwzględnieniem okresu wczesnego dzieciństwa. Jego zainteresowania badawcze koncentrują się wokół problematyki funkcjonowania poznawczego dzieci i jego związku z edukacją szkolną. Wiele prac badawczych poświęcił on zgłębianiu dziecięcej świadomości poznawczej, procesowi rozwiązywania problemów, uczeniu się przez zabawę i rozwojowi samoregulacji u dzieci. Temat wykładu: Zabawa i uczenie się dzieci a wiek rozpoczynania edukacji szkolnej-fakty i mity nawiązywał do powszechnie panującej tendencji do obniżania wieku realizacji obowiązku szkolnego.

David Whitebread stwierdził na wstępie, że polski rząd nie jest jedynym, który podejmuje działania zmierzające do obniżenia tego wieku. W wielu krajach na świecie obserwuje się trend do coraz wcześniejszej formalizacji edukacji szkolnej. Na przykład w Wielkiej Brytanii obowiązek szkolny obejmuje dzieci 5-letnie, ale w praktyce naukę szkolną podejmują już 4-latki. Prelegent postawił podstawowe pytanie: czy tak wczesna edukacja w środowisku szkolnym przynosi oczekiwane rezultaty? Odpowiadając na nie, przytoczył wyniki badań National Foundation for Educational Research w Wielkiej Brytanii, które wskazują, że może ona zwiększać zaburzenia emocjonalne u dzieci, głównie lęk, ponadto wpływać na poczucie własnej wartości i motywację do uczenia się. Nie udało się jednak ustalić optymalnego wieku do rozpoczęcia edukacji szkolnej, tak żeby to wydarzenie pozytywnie stymulowało odroczone w czasie osiągnięcia edukacyjne. W większości krajów na świecie dzieci obowiązkowo idą do szkoły w wieku 6 lub 7 lat, zdaniem Davida Whitebreada podjęcie tego rodzaju aktywności na tym etapie życia jest korzystne. Gość z Wielkiej Brytanii przytoczył znane badania PISA (Program Międzynarodowej Oceny Umiejętności Uczniów) prowadzone w 55 krajach, które 
pozwalają na konstatację, że wcześniejsze rozpoczęcie nauki czytania nie ma związku z wyższymi osiągnięciami czytelniczymi w wieku 15 lat. Inne badania wskazują, że dzieci, które później nauczyły się czytać, w wieku 11 lat częściej wykorzystują tę umiejętność i lepiej rozumieją tekst niż te, które były uczone czytania w wieku wcześniejszym.

W toku wykładu David Whitebread stwierdził, że edukacja przedszkolna oparta na swobodnej zabawie, eksploracji środowiska i kontaktach z rówieśnikami jest związana z lepszymi wynikami w nauce i wyższą motywacją do podejmowania różnych aktywności poznawczych pod koniec szkoły podstawowej. Wymaganie od małych dzieci nauki w warunkach szkolnych, w sytuacji, kiedy nie mają one odpowiedniej dojrzałości intelektualnej, emocjonalnej i społecznej, prowadzi do wczesnego doznawania porażek i skutkuje brakiem zainteresowania nauką w wieku późniejszym.

W dalszej części wykładu prelegent zaprezentował rozważania na temat roli zabawy w wieku przedszkolnym i jej związku z przygotowywaniem się do realizacji obowiązku szkolnego. Odwołał się przy tym do dorobku psychologii ewolucyjnej, antropologii, nauk kognitywnych i psychologii rozwojowej, wykazując, że w okresie wczesnego dzieciństwa zabawa i uczenie się są ze sobą nierozerwalnie związane i mają dla rozwoju dziecka nieocenione znaczenie. Swobodna zabawa kreuje zdolności poznawcze, wspiera rozwój języka i myślenia symbolicznego oraz decyduje o dobrostanie psychicznym dziecka. David Whitebread wyodrębnił pięć typów zabaw, obserwowanych w wieku dziecięcym: zabawę sensomotoryczną, symboliczną, fikcyjną, z przedmiotami i z ustalonymi regułami. Każda z tych aktywności zabawowych przynosi wymierne korzyści prorozwojowe. W zabawach o charakterze sensomotorycznym dzieci wzmacniają siłę fizyczną, wytrzymałość, uczą się koordynacji wzrokowo-ruchowej, a także umiejętności społecznych $\mathrm{i}$ emocjonalnych $\mathrm{w}$ kontaktach $\mathrm{z}$ rówieśnikami. Zabawy symboliczna i fikcyjna przyczyniają się do wzrostu kompetencji językowych dziecka oraz umiejętności czytania i liczenia, ułatwiają wchodzenie w relacje społeczne, a także wspomagają zdolności artystyczne. Zabawa z przedmiotami sprzyja rozwijaniu myślenia i umiejętności rozwiązywania problemów, a także wspiera kreatywność. Zabawy z regułami pozwalają dzieciom na tworzenie i stosowanie reguł, rozwijają zdolności społeczne, empatię i umiejętność dyskutowania.

W wielu krajach zabawa dziecięca jest zdaniem Davida Whitebreada traktowana jako „nieważna aktywność” wynikająca z niedojrzałości dzieci, i z tego powodu bywa niedoceniana. Prelegent podkreślił, że wczesne ograniczenie czasu na rozwój nieskrępowanej zabawy obniża możliwość zdobycia doświadczeń, które są kluczowe w późniejszej edukacji szkolnej. Liczne wyniki badań pokazują, że zabawa jest jednym z największych osiągnięć ludzkości. To ona jest podstawą rozwoju języka, sztuki, kultury, nauki i technologii. Pozbawianie dzieci możliwości zabawy we wczesnym dzieciństwie może przynieść niepowetowane straty w późniejszych okresach rozwojowych. David Whitebread wysunął postulat, żeby wspierać rozwój 
edukacji przedszkolnej i podnosić jej jakość poprzez: zapewnienie dzieciom zabawy z rówieśnikami, dostarczenie niezbędnych materiałów i środków, dbałość o kształcenie profesjonalnej kadry nauczycielskiej.

Wykład spotkał się dużym zainteresowaniem studentów, wykładowców, nauczycieli wczesnej edukacji oraz licznie przybyłych gości. Problematyka obniżenia wieku rozpoczynania edukacji szkolnej w Polsce jest obecnie ważnym zagadnieniem, będącym przedmiotem dyskusji i rozważań w przestrzeni społecznej. Stanowisko i poglądy prelegenta poparte wynikami wieloletnich badań wskazują, że należy bardzo rozważnie podejmować decyzje, które zadecydują o przyszłości edukacji w Polsce i kształceniu przyszłych pokoleń polskich uczniów.

Ewa Kulawska UKSW, Warszawa 